\title{
DISTORSI KAPASITAS PERDAGANGAN INTER-REGIONAL IMT-GT Kasus Provinsi Terpilih di Sumatera Indonesia
}

\author{
Benito Rio Avianto ${ }^{1}$ dan Raldi Hendro Koestoer ${ }^{2}$ \\ ${ }^{1}$ Kantor Menko Perekonomian Republik Indonesia \\ Jalan Lapangan Banteng Timur Nomor 2-4 Jakarta Pusat 10710, Telp: 021-3521835 \\ 2 Pusat Penelitian Kependudukan (P2K) Lembaga Ilmu Pengetahuan Indonesia \\ Gedung Widya Graha LIPI lantai 10 Jalan Gatot Subroto 10 Jakarta 12710 Telepon: 021-5221687
}

\section{Diterima 5 Januari 2010/ Disetujui 17 April 2010}

\begin{abstract}
The objective of the paper was to understand the impact of sub regional economic cooperation, known as the Indonesia-Malaysia-Thailand Growth Triangle (IMT-GT), on trade sector in Indonesia. The approach of research based on export macro information by provinces and commodities. The method used in the analytical framework was a fixed effect method. The regional study covered Nanggroe Aceh Darussalam, North Sumatera, West Sumatera, and Riau provinces, and the commodities involved CPO, coffee and rubber, with 1990-2008 data series. Based on pooled regression, there was a significant impact on export from the four provinces to Malaysia and Thailand for all based years. One might focus on commodity level that, in fact, CPO was the only one commodity that had a significant impact within the IMTGT region. In addition, Thai Bath and Malaysian Ringgit, with respect to GDP for both countries, had significant influenced on export, especially after the IMT-GT endorsed.
\end{abstract}

Keywords: IMT-GT, pooled regression, trade capacity, economic cooperation

\begin{abstract}
Abstrak: Tujuan penelitian ini untuk memahami dampak kerja sama ekonomi subregional, yang dikenal sebagai Indonesia-Malaysia-Thailand Growth Triangle (IMT-GT), pada sektor perdagangan di Indonesia. Pendekatan penelitian berdasarkan informasi makro ekspor per provinsi dan komoditas. Metode yang digunakan dalam kerangka analitis adalah metode fixed effect. Penelitian meliputi wilayah Nanggroe Aceh Darussalam, Sumatera Utara, Sumatera Barat, dan provinsi Riau, sedangkan komoditas yang diteliti yaitu CPO, kopi, dan karet, dengan data penelitian selama tahun 1990-2008. Berdasarkan model pool regresi diketahui ada dampak yang signifikan terhadap ekspor dari empat provinsi tersebut ke negara tujuan Malaysia dan Thailand setiap tahunnya. CPO menjadi satu-satunya komoditas perdagangan yang berdampak signifikan di wilayah segitiga pertumbuhan IMT-GT. Di samping itu, mata uang Bath Thailand dan Ringgit Malaysia dengan memperhatikan PDB kedua negara tersebut, berpengaruh signifikan terhadap ekspor terutama setelah disahkannya IMT-GT.
\end{abstract}

Kata kunci: IMT-GT, pooled regression, kapasitas perdagangan, kerjasama ekonomi

\section{PENDAHULUAN}

Globalisasi ekonomi merupakan suatu realita yang dihadapi banyak negara di dunia saat ini, termasuk Indonesia. Hal tersebut seperti di ucapkan oleh Presiden Suharto dalam perte- muan puncak Pemimpin Asia Pacific Economic Coperation (APEC) di Bogor tahun 1994, "Indonesia harus mengambil bagian dari globalisasi" (Soesastro, 2004:12). IMT-GT merupakan suatu bentuk kerjasama subregional yang lebih luas cakupannya dibandingkan SIJORI (Singapore, Johor dan Riau), yakni mencakup sepuluh pro- 
vinsi di Sumatera, delapan negara bagian di Malaysia, dan empat belas provinsi di selatan Thailand.

Pembentukan IMT-GT dapat dikatakan merupakan tindak lanjut dan pengembangan kerja sama di antara pengusaha-pengusaha swasta dari Indonesia, Malaysia, dan Thailand yang telah mempunyai hubungan historis karena posisi wilayahnya yang berdekatan. Pengembangan kerjasama ekonomi subregional IMT-GT merupakan salah satu upaya pemerintah dalam rangka meningkatkan kesejahteraan masyarakat secara merata dan berkesinambungan yaitu dengan meningkatkan pendayagunaan sumber daya manusia dan alam dari masing-masing wilayah.

Terkait dengan KESR IMT-GT timbul suatu pertanyaan, bagaimana pengaruh kerjasama ekonomi subregional terhadap ekspor Indonesia terutama dari provinsi di Sumatera ke Malaysia dan Thailand yang terlibat dalam KESR tersebut? Bagaimanakah pengaruhnya terhadap ekspor komoditas utama provinsi di Sumatera? Faktor-faktor apa sajakah yang mempengaruhi ekspor provinsi Sumatera ke Malaysia dan Thailand baik secara agregatif maupun dirinci menurut komoditas utama sebelum dan sesudah IMT-GT?

Sektor yang dipilih dalam penelitian ini adalah sektor perdagangan. Sektor perdagangan makro regional ini dipilih karena dapat memberikan 'warna' langsung terhadap perekonomian regional di Sumatera. Empat provinsi (NAD, Sumbar, Sumut dan Riau) dipertimbangkan memiliki potensi unggulan sektor, dan juga telah meningkatkan daya saing ekspornya (ADB, 2007:5). Beberapa tinjauan studi mendasar dalam kajian ini adalah memfokus pada: (1) sisi permintaan ekspor (total demand); (2) ekspor NAD, Sumatera Utara, Sumatera Barat, dan Riau provinsi; (3) nilai ekspor komoditas CPO, kopi, dan karet tanpa membedakan jenis maupun kualitas.

Studi ini bertujuan mengulas: (1) dampak integrasi perekonomian negara ASEAN dalam skala subregional terhadap ekspor NAD, Sumatera Utara, Sumatera Barat, dan Riau ke Malaysia dan Thailand sebelum dan sesudah IMT-GT; (2) dampak integrasi perekonomian negara ASEAN dalam skala subregional ter- hadap ekspor produk CPO, kopi, dan karet ke Malaysia dan Thailand sebelum dan sesudah Keppres No. 13 tahun 2001 tentang IMT-GT; dan (3) faktor-faktor yang berpengaruh terhadap ekspor NAD, Sumatera Utara, Sumatera Barat, dan Riau ke Malaysia dan Thailand baik secara agregatif maupun menurut komoditas CPO, kopi, dan karet sebelum dan sesudah IMT-GT.

Data yang digunakan berasal dari data makro regional Badan Pusat Statistik (BPS) tahun 1990-2008 khususnya untuk pengamatan nilai ekspor secara agregat, dan data tahun 1998-2008 menurut komoditas CPO, kopi, dan karet. Pilihan tinjauan komoditas adalah didasarkan pada kapasitas unggulan Sumatera (Kasman, 2009).

Meskipun telah banyak mengadakan kerjasama ekonomi internasional yang jumlahnya mencapai puluhan (Departemen Luar Negeri, 2007: 6), tetapi masih terbatas penelitian tentang manfaat kerjasama ekonomi internasional tersebut bagi Indonesia. Penelitian yang ada lebih banyak meneliti dampak kerjasama ekonomi internasional pada tingkatan negara (bersifat agregatif).

Hipotesis dalam riset ini disederhanakan dalam dua arahan: (1) diduga terjadi perbedaan nilai ekspor baik secara agregatif maupun perkomoditas CPO, kopi, dan karet dari NAD, Sumatera Utara, Sumatera Barat, dan Riau sebelum dan sesudah IMT-GT; (2) diduga kurs Ringgit, kurs Bath, inflasi Malaysia, inflasi Thailand, GDP per kapita Malaysia, GDP per kapita Thailand, harga internasional komoditas $\mathrm{CPO}$, kopi, dan karet berpengaruh terhadap nilai ekspor NAD, Sumatera Utara, Sumatera Barat, dan Riau baik secara agregatif maupun menurut komoditas CPO, kopi, dan karet.

Informasi Makro Interwilayah Perdagangan ke Malaysia dan Thailand. Kerjasama Ekonomi Sub-Regional (KESR) merupakan forum kerjasama ekonomi mencakup daerah geografis yang berdekatan dengan melintasi batas dua, tiga negara atau lebih, dan bertujuan menciptakan perdagangan sebagai strategi kunci dari pemerintah untuk berpartisipasi dalam mengangkat perkembangan sosial dan ekonomi wilayah mereka yang kurang berkembang dan terpencil guna menjalankan proses integrasi 
ekonomi sebagai zona investasi yang berorientasi ke pasar internasional (Sahman, 2007:1). Secara nyata, perkembangan pengelompokan subwilayah ini terletak pada sektor swasta sebagai penggerak pertumbuhan dengan pemerintah sebagai pihak yang menyediakan fasilitas pendukung.

Salah satu penelitian yang telah dilakukan adalah penelitian KESR oleh Jitpiromsri dan Kitthaworn (2000) dengan bantuan dari ADB, yaitu tentang implikasi dari "Open Regionalism" kerjasama IMT-GT terhadap perekonomian lokal di Thailand tahun 1998. Hasil penelitian menunjukkan dapat diidentifikasikannya keunggulan masyarakat Thailand di provinsi Pattani, Yala, Narathiwat, Satun, dan Songkla dibandingkan dengan Indonesia dan Malaysia.

Perdagangan internasional dapat didefinisikan sebagai perdagangan antarnegara yang pada prinsipnya merupakan perdagangan antara dua negara yang mencakup ekspor dan impor (Tambunan, 2000:1). Menurut Mankiw (2006:128), ekspor suatu negara dipengaruhi oleh nilai kurs, inflasi negara tujuan, dan GDP per kapita negara tujuan ekspor. Boediono (1993:34) mengatakan manfaat langsung dari perdagangan internasional adalah meningkatnya hasil produksi dan pendapatan produsen, bertambahnya lapangan pekerjaan dan keterampilan serta mendorong perbaikan mutu barang yang diperdagangkan.

Dosch dan Hensengerth (2005) menganalisis tentang kerjasama subregional di Asia Tenggara: the Greater Mekong Basin (GMS). Untuk itu diperlukan kerjasama subregional GMS, yang bertujuan sebagai upaya-upaya menanggulangi konflik-konflik tersebut. Tujuan utama kerjasama GMS adalah menciptakan keamanan dan stabilitas wilayah. ERIA (Economic Research Institute for Asean and East Asia) sejak 2007-2009 telah melakukan ulasan perkembangan spatial perkotaan di GMS, IMT GT dan BIMP EAGA di bidang industri manufaktur (Koestoer, 2009). Pada dasarnya ERIA meninjau ranah studi yang lebih luas hingga mencakup GMS, IMT dan BIMP (Brunei, Indonesia Malaysia dan Philipines) dan ditinjau ulang oleh Koestoer (2009) terhadap mekanisme inter-regional dan pengelolaan kelembagaannya dalam konteks megalopolis, ketimbang sektor ekonomi, terutama bagi IMT.

Feng dan Genna (2003:14) mengatakan integrasi ekonomi didefinisikan sebagai bentuk tindakan bersama secara kolektif di antara beberapa negara untuk mencapai tujuan yang telah disepakati. Tindakan ini dapat berupa pembentukan free trade area, customs union, sampai economic union seperti yang telah dicapai Masyarakat Ekonomi Eropa (MEE). Rodrik (2000), integrasi ekonomi internasional adalah bagaimana memandang dunia ini sebagai pasar untuk barang, jasa, dan pasar produksi terintegrasi secara sempurna.

Sebagaimana telah dikemukakan di atas, sektor perdagangan merupakan salah satu prioritas dalam kerjasama IMT-GT. Kegiatan sektor perdagangan tersebut diharapkan dapat menjadi motor penggerak bagi pertumbuhan ekonomi daerah. Perkembangan sektor perdagangan dari Indonesia ke Malaysia dan Thailand dapat dilihat pada Gambar 1.

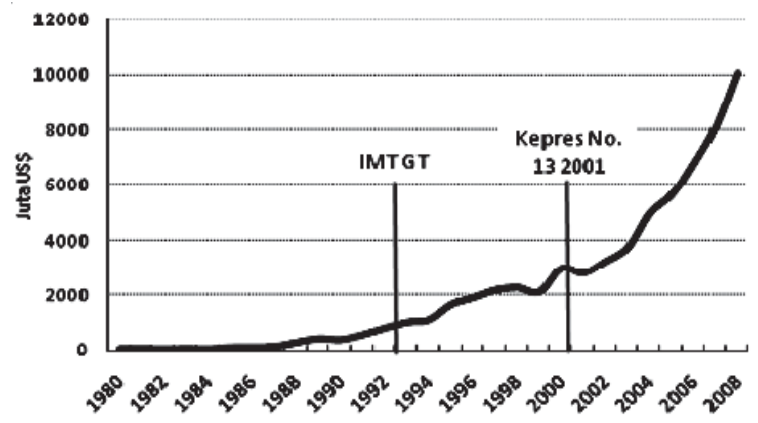

Sumber: BPS, Statistik Indonesia 1980-2008, diolah

\section{Gambar 1. Perkembangan Ekspor Indonesia ke Malaysia dan Thailand, 1980-2008}

Perkembangan ekspor Indonesia sebelum dan setelah diterbitkannya Keppres KESR secara historis dari tahun 1990 sampai 2008 relatif meningkat. Gambar 1 menunjukkan bahwa pada tahun 1980-1992 sebelum disepakati IMT-GT, nilai ekspor Indonesia ke Malaysia dan Thailand bergerak sangat lambat, yakni di bawah US\$1.000 juta. Namun, setelah terbitnya Keppres No. 13 tahun 2001 tentang penguatan Kerjasama Ekonomi Sub Regional/KESR, ekspor Indonesia mengalami kenaikan cukup berarti yakni mendekati US $\$ 2.000$ juta pada tahun 1994 dan mengalami lonjakan dua kali 


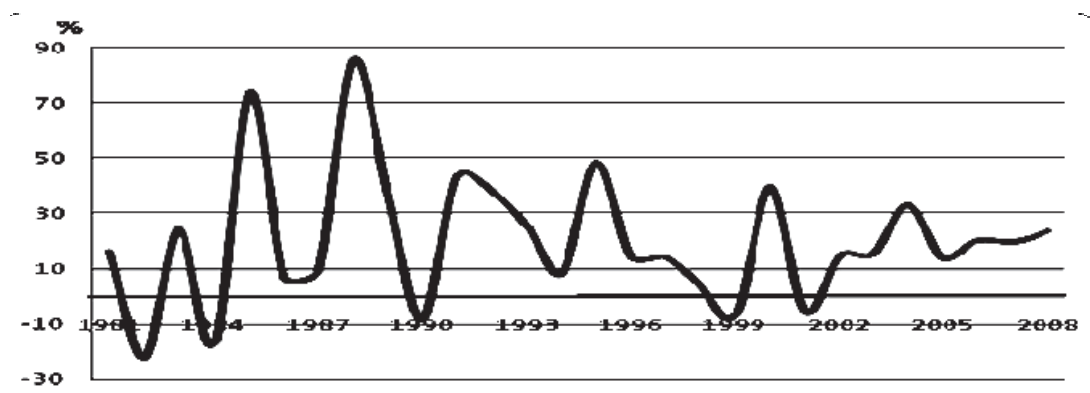

Sumber: BPS, Statistik Indonesia 1980-2008, diolah

Gambar 2. Pertumbuhan Ekspor Indonesia ke Malaysia dan Thailand, 1981-2008

lipat yakni mencapai sekitar US\$ 4.000 juta pada tahun 2002.

Dalam kurun waktu 1981-2008, tampak secara umum ekspor Indonesia ke Malaysia dan Thailand mengalami pertumbuhan positif, lihat Gambar 2. Pertumbuhan tertinggi terjadi pada akhir tahun tahun 1980-an. Pada masa krisis ekonomi tahun 1998-1999 ekspor Indonesia ke Malaysia dan Thailand mengalami kontraksi hingga tumbuh negatif. Setelah masa pemulihan ekonomi (economic recovery) tahun 2002-2008, pertumbuhan ekspor Indonesia ke Malaysia dan Thailand mengalami pertumbuhan positif di kisaran 30 persen.

Gambar 3 menunjukkan perkembangan ekspor dan impor ke Malaysia dan Thailand selama tahun 1990-2008. Tampak pada Gambar 3 perkembangan ekspor dan impor ke Malaysia dan Thailand sama-sama menunjukkan kecenderungan meningkat dari tahun ke tahun.

Dalam perkembangan neraca perdagangan Indonesia ke Malaysia dan Thailand dalam kurun waktu 1990-2008, pola kecenderungan perdagangan Indonesia mengalami fluktuasi yang tidak terduga. Hal ini ditunjukkan pada Gambar 4. Tampak bahwa mulai tahun 2006, neraca perdagangan Indonesia ke Malaysia dan Thailand mengalami kontraksi sampai US\$ (-) 5.200 juta, artinya selisih ekspor dengan kurangi impor ke Malaysia dan Thailand mengalami selisih yang sangat besar.

\section{Pendekatan Dasar}

Guna mem'bongkar' permasalahan dan mencapai tujuan studi digunakan pendekatan beberapa uji statistik yang relevan, antara lain: (1) Uji Beda Rata-rata dan (2) Analisis Regresi Data Panel. Uji Beda Rata-rata digunakan untuk merujuk pada perbedaan pengaruh sebelum dan setelah diberlakukannya penetapan KESR, khususnya IMT-GT (Indonesia, Malaysia and Thailand Growth Triangle). Untuk mengetahui pengaruh sebelum dan sesudah IMT-GT baik pada nilai ekspor NAD, Sumatera Utara, Sumatera Barat, dan Riau baik secara agregatif maupun menurut komoditas $\mathrm{CPO}$, kopi, dan karet, digunakan uji tanda dan uji peringkat Wilcoxon-Mann-Whitney (statistik WMW).

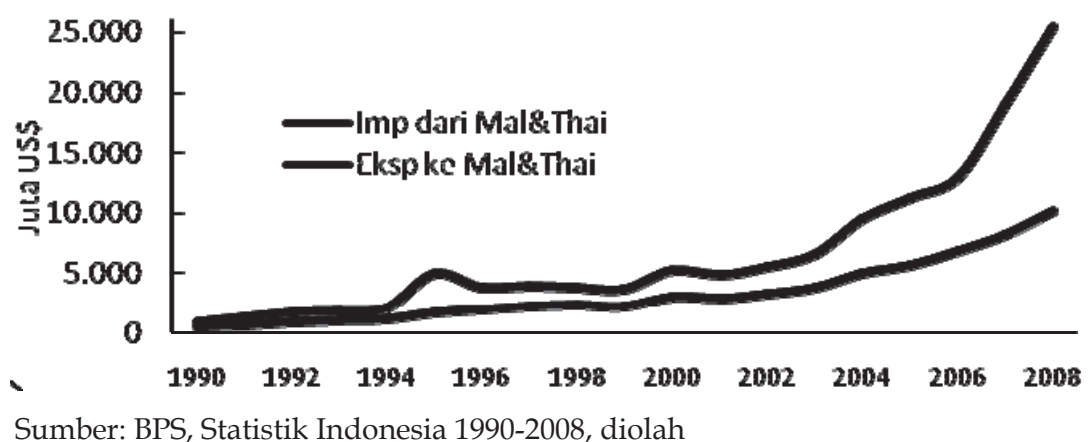

Gambar 3. Ekspor dan Impor Indonesia ke Malaysia dan Thailand, 1981-2008 


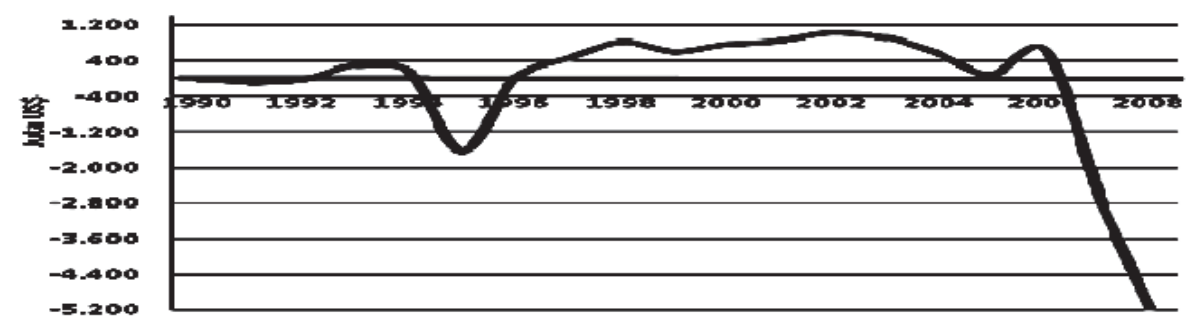

Sumber: BPS, Statistik Indonesia 1990-2008, diolah penulis.

Gambar 4. Neraca Perdagangan Indonesia ke Malaysia dan Thailand, 1981-2008

Statistik Uji WMW, Z $=\frac{\left(W_{+}-\mu_{w+}\right)}{\sigma_{w+}}$

Keterangan: W+ adalah jumlah selisih nilai ekspor NAD, Sumatera Utara, Sumatera Barat, dan. Riau sebelum dan sesudah IMT-GT; $\mu w^{+}$ adalah nilai rata-rata selisih nilai ekspor NAD, Sumatera Utara, Sumatera Barat, dan Riau sebelum dan sesudah IMT-GT; $\boldsymbol{\sigma}_{\mathbf{w}+}$ adalah nilai simpangan baku selisih nilai ekspor NAD, Sumatera Utara, Sumatera Barat, dan Riau sebelum dan sesudah IMT-GT.

Untuk mengetahui pengaruh sebelum dan sesudah IMT-GT pada nilai nilai ekspor NAD, Sumatera Utara, Sumatera Barat, dan Riau, baik secara agregatif maupun menurut komoditas $\mathrm{CPO}$, kopi, dan karet, beserta faktor-faktor yang mempengaruhinya, dipergunakan analisis regresi data panel. Variabel dummy digunakan untuk melihat pengaruh sebelum dan sesudah IMT-GT.

Secara umum kerangka dasar data panel dapat ditulis sebagai berikut,

$y_{i t}=x_{i t}^{\prime} \beta_{i t}+\varepsilon_{i t}$

di mana $\beta_{i t}$ mengukur pengaruh dari $x_{i t}$ dalam periode $t$ untuk unit $i$. Asumsi standar yang digunakan dalam studi empiris menyatakan, bahwa $\beta_{i t}$ konstan untuk semua $i$ dan $t$ kecuali - mungkin- untuk intersep. Hal ini dapat ditulis sebagai berikut,

$y_{i t}=\alpha_{i}+x^{\prime}{ }_{i t} \beta_{i t}+\varepsilon_{i t}$

di mana $x_{i t}$ adalah vektor berdimensi $\mathrm{k}$ dari variabel penjelas, tidak termasuk konstanta. Hal ini berarti, bahwa efek dari perubahan $x$ adalah sama untuk setiap unit dan semua periode, tetapi rata-rata dari unit $i$. mungkin berbeda dari unit j. $\alpha_{i}$ menangkap efek dari variabel-variabel tersebut yang khas untuk individu ke-i dan konstan sepanjang waktu.

Pada penelitian ini terdapat 76 data untuk model ekspor provinsi secara agregatif, dan 99 data untuk model ekspor komoditas. Model regresi data panel tersebut secara ekonometrik dapat dituliskan sebagai berikut;

(1) Ekspor agregat NAD, Sumatera Utara, Sumatera Barat, dan Riau secara agregat sebelum dan sesudah IMT-GT.

$$
\begin{aligned}
E_{i t}= & a_{1}+a_{2} D_{2 i}+a_{3} D_{3 i}+a_{4} D_{4 i}+\beta_{2} X_{2 i t}+\beta_{3} X_{3 i t}+ \\
& \beta_{4} X_{4 i t}+\beta_{5} X_{5 i t}+\beta_{6} X_{6 i t}+\beta_{7} X_{7 i t}+u_{i t}
\end{aligned}
$$

Keterangan: E adalah nilai ekspor ke Malaysia dan Thailand (juta US\$); $\mathbf{X}_{\mathbf{2}}$ adalah kurs Ringgit terhadap Rupiah; $\mathbf{X}_{3}$ adalah kurs Bath terhadap Rupiah; $\mathbf{X}_{\mathbf{4}}$ adalah tingkat inflasi Malaysia (\%); $\mathbf{X}_{5}$ adalah tingkat inflasi Thailand $(\%) ; \mathbf{X}_{6}$ adalah GDP per kapita Malaysia (US\$); $\mathbf{X}_{7}$ adalah GDP per kapita Thailand (US\$); $\mathbf{i}$ adalah NAD, Sumut, Sumbar, Riau; $\mathbf{t}$ adalah 1990-2008; D adalah variabel dummy; $\mathbf{D}_{2 \mathrm{i}}=1$ jika observasinya NAD, dan 0 jika bukan; $\mathrm{D}_{3 \mathrm{i}}=1$ jika observasinya Sumut, dan 0 jika bukan; $\mathbf{D}_{4 \mathrm{i}}=1$ jika observasinya Sumbar, dan 0 jika bukan; $\mathbf{a}_{1 . . .}$ $\boldsymbol{\alpha}_{4}, \boldsymbol{\beta}_{2} \ldots \boldsymbol{\beta}_{7}$ adalah koefisien; $\mathbf{u}$ adalah faktor pengganggu.

(2) Ekspor agregat NAD, Sumatera Utara, Sumatera Barat, dan Riau menurut komoditas CPO, kopi, dan karet sebelum dan sesudah IMT-GT.

$$
\begin{aligned}
E_{i t k}= & a_{1}+a_{2} D_{2 t k}+a_{3} D_{3 t k}+a_{4} D_{4 t k}+\beta_{2} X_{2 i t k}+ \\
& \beta_{3} X_{3 i t k}+\beta_{4} X_{4 i t k}+\beta_{5} X_{5 i t k}+\beta_{6} X_{6 i t k}+\beta_{7} X_{7 i t k}+ \\
& \beta_{8} X_{8 i t k}+u_{i t k}
\end{aligned}
$$


Keterangan: E adalah nilai ekspor komoditas ke Malaysia dan Thailand (10.000 US\$); $\mathbf{X}_{2}$ adalah kurs Ringgit terhadap Rupiah; $\mathbf{X}_{3}$ adalah kurs Bath terhadap Rupiah; $\mathbf{X}_{\mathbf{4}}$ adalah tingkat inflasi Malaysia (\%); $\mathbf{X}_{5}$ adalah tingkat inflasi Thailand (\%); $\mathbf{X}_{6}$ adalah GDP per kapita Malaysia (US\$); $\mathbf{X}_{7}$ adalah GDP per kapita Thailand (US\$); $\mathbf{X}_{8}$ adalah harga internasional komoditas; i adalah NAD, Sumut, Sumbar, Riau; $\mathbf{t}$ adalah 1990-2008; k adalah CPO, kopi, karet; $\mathbf{D}$ adalah variabel dummy; $\boldsymbol{D}_{2 t k}=1$ jika observasinya NAD, dan 0 jika bukan; $D_{3 t k}=1$ jika observasinya Sumut, dan 0 jika bukan; $\boldsymbol{D}_{4 t k}=1$ jika observasinya Sumbar, dan 0 jika bukan; $a_{1} \ldots a_{4}, \beta_{2 \ldots} \beta_{8}$ adalah Koefisien parameter; $\mathrm{u}$ adalah Faktor pengganggu.

\section{HASIL DAN PEMBAHASAN}

Data set yang dikumpulkan digunakan untuk mengamati ekspor provinsi NAD, Sumatera Utara, Sumatera Barat, dan Riau dalam kurun waktu 19 tahun yakni dari tahun 1990-2008. Untuk data ekspor komoditas CPO, kopi, dan karet dari NAD, Sumatera Utara, Sumatera Barat, dan Riau, data yang berhasil dikumpulkan untuk kurun waktu 11 tahun yakni dari tahun 1998-2008.

\section{Perkembangan Ekspor Provinsi NAD, Su- matera Utara, Sumatera Barat, dan Riau ke Malaysia dan Thailand}

Provinsi NAD, Sumatera Utara, Sumatera Barat, dan Riau merupakan empat provinsi di Pulau Sumatera yang terlibat dalam KESR IMTGT. Perkembangan ekspor provinsi NAD, Sumatera Utara, Sumatera Barat, dan Riau ke
Malaysia dan Thailand tahun 1990-2008 dapat dilihat pada Gambar 5.

Gambar 5 menunjukkan perkembangan nilai ekspor provinsi NAD, Sumatera Utara, Sumatera Barat, dan Riau tahun 1990-2008 sangat beragam. Tampak pada Gambar 5, walaupun berfluktuatif Riau mempunyai nilai ekspor terbesar di antara provinsi lainnya. Selain itu, Riau juga mempunyai trend pertumbuhan positif dalam mengekspor produknya ke Malaysia dan Thailand.

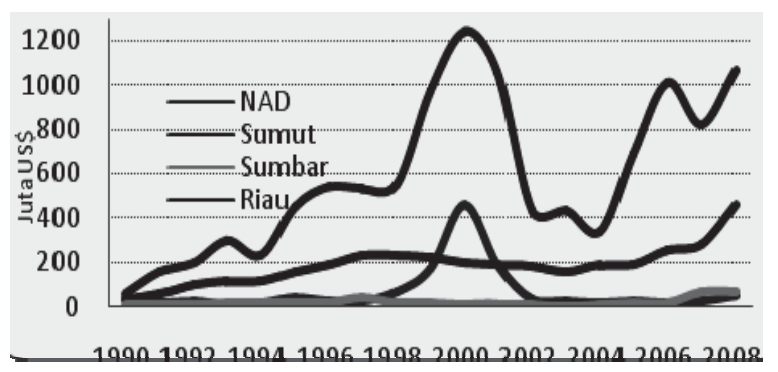

Sumber: BPS NAD, Sumatera Barat, Sumatera Utara, dan Riau, NAD, Sumatera Barat, Sumatera Utara, dan Riau Dalam Angka, 1990-2008,

Gambar 5. Perkembangan Ekspor ke Malaysia dan Thailand menurut Provinsi 1990-2008

Bila dilihat dari sisi pertumbuhan seperti terlihat dalam Gambar 6, tampak ke empat provinsi penelitian memiliki pertumbuhan yang fluktuatif dalam periode 1991-2008. Sumatera Barat dan NAD memiliki fluktuasi pertumbuhan paling beragam, sedangkan Riau dan Sumatera Utara relatif stabil.

Perkembangan ekspor CPO, kopi, karet dari provinsi NAD, Sumatera Utara, Sumatera Barat, dan Riau ke Malaysia dan Thailand.

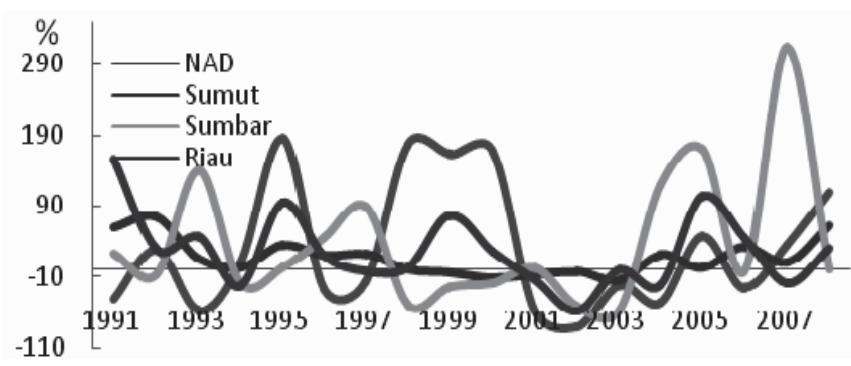

Sumber: BPS NAD, Sumatera Barat, Sumatera Utara, dan Riau, NAD, Sumatera Barat, Sumatera Utara, dan Riau dalam Angka, 1990- 2008, diolah.

Gambar 6. Pertumbuhan Ekspor ke Malaysia dan Thailand menurut Provinsi, 1990-2008 
Thailand mencapai sekitar US\$ 40 ribu, yang nilainya relatif kecil dibandingkan ekspor $\mathrm{CPO}$ dan kopi.

Analisis Uji Beda Rata-Rata Ekspor Provinsi NAD, Sumatera Utara, Sumatera Barat, dan Riau ke Malaysia dan Thailand

Setelah dilakukan penghitungan terhadap uji beda rata-rata terhadap nilai ekspor provinsi NAD, Sumatera Utara, Sumatera Barat, dan Riau didapatkan hasil pada Tabel 1.

Tabel 1. Uji Beda Rata-rata Ekspor NAD, Sumut, Sumbar, dan Riau sebelum dan Sesudah IMT-GT

\begin{tabular}{lc}
\hline & Sesudah - Sebelum \\
\hline$Z$ & $-3,103^{\mathrm{a}}$ \\
Asymp. Sig. (2-tailed) &, 002 \\
\hline
\end{tabular}

a. Based on negative ranks.

b. Wilcoxon Signed Ranks Test

Hipotesis (Ho) dalam penelitian ini adalah $\mathrm{Ho}=0$, yaitu tidak terdapat perbedaan yang signifikan nilai ekspor provinsi NAD, Sumatera Utara, Sumatera Barat, dan Riau sebelum dan sesudah IMT-GT. Secara agregatif terjadi perbedaan yang signifikan total nilai ekspor provinsi NAD, Sumatera Utara, Sumatera Barat, dan Riau ke Malaysia dan Thailand. Hal ini ditunjukkan oleh nilai signifikansi sebesar 2 persen, dimana nilai signifikansi tersebut berada di bawah batas $\mathrm{a}=5$ persen yang berarti tolak Ho.

Pada Tabel 2 ditunjukkan hasil uji beda rata-rata pada provinsi NAD, Sumatera Utara, Sumatera Barat, dan Riau ke Malaysia dan Thailand.

Tabel 2. Uji Beda rata-rata Ekspor Menurut Provinsi Sebelum dan Sesudah IMT-GT

\begin{tabular}{lrrrr}
\hline & NAD & Sumut & Sumbar & Riau \\
\hline$Z$ &,$- 365 a$ & $-1,826^{a}$ & $-1,826^{a}$ & $-1,826^{a}$ \\
$\begin{array}{l}\text { Asymp.Sig. } \\
\text { (2-tailed) }\end{array}$ &, 715 &, 068 &, 068 &, 068 \\
\hline
\end{tabular}

a. Based on negative ranks.

b. Wilcoxon Signed Ranks Test
Terlihat bahwa nilai ekspor dari dari Sumatera Utara, Sumatera Barat, dan Riau berbeda secara signifikan pada $a=10$ persen, di mana nilai signifikansinya 6,8 persen sebelum dan sesudah IMT-GT. Ekspor dari NAD tidak berbeda secara signifikan sebelum dan sesudah IMT-GT.

Analisis Uji Beda Rata-rata Ekspor CPO, Kopi, dan Karet dari Provinsi NAD, Sumatera Utara, Sumatera Barat, dan Riau ke Malaysia dan Thailand

Setelah dilakukan penghitungan terhadap uji beda rata-rata terhadap nilai ekspor CPO, kopi, dan karet provinsi NAD, Sumatera Utara, Sumatera Barat, dan Riau didapatkan hasil pada Tabel 3.

Tabel 3. Uji Beda Rata-rata Ekspor CPO, Kopi, dan Karet Sebelum dan Sesudah IMTGT

\begin{tabular}{lcll}
\hline & CPO & Kopi & Karet \\
\hline $\mathrm{Z}$ & $-1,503(\mathrm{a})$ &,$- 357(\mathrm{a})$ &,$- 447(\mathrm{a})$ \\
$\begin{array}{c}\text { Asymp. Sig. } \\
\text { (2-tailed) }\end{array}$ &, 133 &, 721 &, 655 \\
\hline
\end{tabular}

a Based on negative ranks.

b Wilcoxon Signed Ranks Test

Tabel 3 menunjukkan uji beda rata-rata ekspor CPO, kopi, dan karet. Tampak pada Tabel 3 nilai sigifikansi $\mathrm{CPO}$, kopi, dan karet adalah 13 persen, 72 persen, dan 65 persen, lebih besar daripada tingkat kesalahan 5 persen. Hal ini berarti menerima Ho, dimana Ho adalah tidak terjadi perbedaan signifikan ekspor CPO, kopi, dan karet sebelum dan sesudah IMT-GT.

Analisis Regresi Data Panel Ekspor Provinsi NAD, Sumatera Utara, Sumatera Barat, dan Riau ke Malaysia dan Thailand

Estimasi Model regresi data panel untuk ekspor provinsi NAD, Sumatera Utara, Sumatera Barat, dan Riau ke Malaysia dan Thailand sebelum dan sesudah IMT-GT mendapatkan hasil seperti terlihat pada Tabel 4. 
variabel dependen dalam model (kurs Bath, inflasi Malaysia, inflasi Thailand, GDP per kapita Malaysia, GDP per kapita, dan variabel dummy) maka besarnya nilai ekspor ke Malaysia dan Thailand dari NAD=US\$9,96 juta, Sumatera Utara $=$ US $\$ 11,45$ juta, Sumatera Barat $=$ US $\$ 8,89$ juta, dan Riau=US\$12,50 juta.

Nilai koefisien variabel independen pada model regresi data panel provinsi NAD, Sumatera Utara, Sumatera Barat, dan Riau dapat diinterpretasikan sebagai berikut:

(1) Apabila kurs ringgit terhadap rupiah naik sebesar 1 unit, maka ekspor akan naik sebesar 0,001 persen; (2) Apabila kurs Bath terhadap rupiah naik sebesar 1 unit, maka ekspor akan turun sebesar 0,01 persen; (3) Apabila inflasi Malaysia naik sebesar 1 persen, maka ekspor akan meningkat sebesar 0,17 persen; (4) Apabila inflasi Thailand naik sebesar 1 persen, maka ekspor akan turun sebesar 0,20 persen; (5) Apabila GDP per kapita Thailand naik sebesar 1 unit, maka ekspor akan meningkat sebesar 0,0006 persen; (6) Pengaruh IMT-GT terhadap ekspor sebesar 0,52 persen.

Berdasarkan estimasi regresi model data panel dapat disimpulkan bahwa kurs ringgit, kurs bath, inflasi Malaysia, inflasi Thailand, GDP per kapita, dan variabel dummy berpengaruh secara signifikan terhadap ekspor provinsi NAD, Sumatera Utara, Sumatera Barat, dan Riau tahun 1990-2008. Besarnya pengaruh tersebut adalah 85 persen.

\section{Analisis Regresi Data Panel Ekspor CPO, Kopi, dan Karet dari Provinsi NAD, Sumatera Utara, Sumatera Barat, dan Riau ke Malaysia dan Thailand}

Pada bagian ini diulas hasil perhitungan menurut Model Regresi Panel Ekspor untuk masingmasing komoditas: CPO, Kopi, dan Karet.

Model regresi panel data ekspor CPO. Hasil pengolahan untuk ekspor CPO dari provinsi NAD, Sumatera Utara, Sumatera Barat, dan Riau ke Malaysia dan Thailand menggunakan bantuan Eviews 4.0 mendapatkan hasil yang tampak dalam Tabel 5.

Tabel 5. Model Regresi Ekspor CPO Provinsi NAD, Sumatera Utara, Sumatera Barat, dan Riau ke Malaysia dan Thailand Sebelum dan Sesudah IMT-GT

\begin{tabular}{lccrc}
\hline Variabel & Coefficient & Std. Error & t-Statistic & Prob. \\
\hline Kurs Ringgit & 0,001047 & 0,001373 & 0,762493 & 0,4569 \\
Kurs Bath & 0,018147 & 0,030786 & 0,589461 & 0,5638 \\
Inflasi Malaysia & 1,121783 & 0,470480 & $2,384334^{*}$ & 0,0298 \\
Inflasi Thailand & $-0,641071$ & 0,404364 & $-1,585383$ & 0,1324 \\
GDP per Kapita Malaysia & $-0,002617$ & 0,001541 & $-1,698332$ & 0,1088 \\
GDP per Kapita Thailand & 0,003415 & 0,003780 & 0,903227 & 0,3798 \\
Harga internasional & $-0,001768$ & 0,009681 & $-0,182640$ & 0,8574 \\
Variabel dummy & 2,563575 & 0,894913 & $2,864608^{*}$ & 0,0112 \\
\hline
\end{tabular}

Keterangan: *) Signifikan pada level 5 persen

Nilai ekspor CPO (independen variabel) dalam bentuk log

\begin{tabular}{llll}
\hline Fixed Effects & & & \\
NAD--C & 9,598585 & & \\
SUMUT--C & 11,86781 & & \\
SUMBAR--C & 9,652886 & & \\
RIAU--C & 12,15419 & & 16,48516 \\
& & & 1,548544 \\
\hline Unweighted Statistics & & & \\
\hline R-squared & 0,711762 & Mean dependent var & \\
Adjusted R-squared & 0,513599 & S.D. dependent var & \\
S.E. of regression & 1,079993 & Sum squared resid & 18,66215 \\
Durbin-Watson stat & 1,349475 & Prob(F-statistic) 0,000000 & \\
\hline
\end{tabular}

Sumber: regresi data panel ekspor CPO provinsi, diolah 


\section{SIMPULAN}

Kesimpulan analisis pengaruh kerjasama ekonomi subregional Indonesia-Malaysia-Thailand Growth Triangle (IMT-GT) terhadap sektor perdagangan di Indonesia adalah sebagai berikut:

Kerjasama ekonomi subregional (KESR) IMT-GT telah memberi pengaruh positif terhadap ekspor baik secara nasional maupun menurut provinsi penelitian.

Menurut ekspor komoditas CPO, kopi, dan karet provinsi NAD, Sumatera Utara, Sumatera Barat, dan Riau ke Malaysia dan Thailand, hanya ekspor CPO yang mendapat pengaruh signifikan sebelum dan sesudah Keppres No. 13 tahun 2001 tentang penguatan KESR IMT-GT. Faktor-faktor yang berpengaruh signifikan terhadap ekspor provinsi NAD, Sumatera Utara, Sumatera Barat, dan Riau ke Malaysia dan Thailand pada KESR IMT-GT adalah kurs Ringgit, kurs Bath, inflasi Malaysia, dan GDP per kapita Thailand, sedangkan faktor yang berpengaruh signifikan terhadap ekspor $\mathrm{CPO}$ adalah inflasi Malaysia.

Implikasi Kebijakan. Berdasarkan kesimpulan di atas, maka dapat diinterpretasikan kebijakan tidak langsung sebagai berikut:

Meninjau potensinya, provinsi NAD, Sumatera Utara, Sumatera Barat, dan Riau, serta seluruh provinsi di Sumatera umumnya dapat memanfaatkan kerjasama IMT-GT yang telah digalang Pemerintah. Perlunya pencatatan data rinci terhadap asal arus barang (rules of origin) antardaerah untuk melihat pengaruh kerjasama ekonomi internasional terhadap daerah. Risetriset sejenis perlu dikembangkan bagi pengulasan nilai impor dan dorongan pencapaian bagi nilai ekspor interwilayah, khususnya difokuskan pada kerjasama subregional. Dibutuhkan kebijakan daerah (ijin dan regulasi yang relevan) guna mendukung dan memacu peningkatan ekspor antarwilayah.

\section{Ucapan Terima Kasih}

Penulis berterimakasih atas komentar pada draf pertama yang diberikan oleh Dr. Catur Sugianto (FE UGM), namun seandainya terjadi kesalahan merupakan tanggung jawab penulis sepenuhnya.

\section{DAFTAR PUSTAKA}

Apriliani, Wiwien, Kevinder, Fitriady, Muhammad. 2008. Teori Regionalism. Jakarta: Central Strategic for International Studies,

Asian Development Bank. 2007. Building A Dynamic Future, Roadmap Development of IMT-GT 2007-2011. Report. IMT-GT Secretariat and Asian Development Bank. Philipines.

Badan Pusat Statistik. 1990-2008. Statistik Indonesia. Jakarta: BPS.

Badan Pusat Statistik. 2008. Kajian komoditas Unggulan 2008. Jakarta: BPS.

Badan Pusat Statistik. 2009. Aceh Dalam Angka 1990-2008. NAD: BPS.

Badan Pusat Statistik. 2009. Kepulauan Riau Dalam Angka 2005-2008. Kepulauan Riau: BPS.

Badan Pusat Statistik. 2009. Riau dalam Angka 1990-2008. Riau: BPS.

Badan Pusat Statistik. 2009. Sumatera Barat dalam Angka 1990-2008. Sumatera Barat: BPS.

Badan Pusat Statistik. 2009. Sumatera Utara Dalam Angka 1990-2008. Sumatera Utara: BPS.

Baltagi, Badi H. 2005. Econometrics Analysis of Panel Data Third Edition. John Wiley. USA.

Bhakti, Anwar, Luhulima, Sungkar, dan Inayanti. 2008. Masyarakat Asia Tenggara Menuju Komunitas ASEAN 2015. Yogyakarta: P2P-LIPI dan Pustaka Pelajar.

Boediono. 1993. Pengantar Ilmu Ekonomi No. 3: Ekonomi Internasional Seri Sinopsis. Yogyakarta: BPFE.

Dajan, Anto. 1991. Pengantar Statistik Jilid II. Cetakan Keempat Belas. Jakarta: LP3ES.

Departemen Luar Negeri. 2007. ASEAN Selayang Pandang. Laporan. Direktorat Jenderal ASEAN. Jakarta: Departemen Luar Negeri. 
Dosch, Jorn dan Hensengerth, Oliver. 2005. Subregional Cooperation in the Southeast Asia: the Mekong Basin. Netherland: Brill. Leiden.

ERIA (Economic Research Institute for Asean and East Asia). 2009. ERIA: The Progress Report. June 2009. Jakarta.

Feng, Yi dan Genna, Gaspare M. 2003. Regional Integration and Domestic Institutional Homogeneity, A Comparative Analysis of Regional Integration in the Americas, Pacific Asia and Western Europe. Review of International Political Economy Vol. 10. No. 2. May 2003. Taylor and Francis Ltd. United Kingdom.

Gajdos, Peter (ed.). 2008. Regional Disparities in Central Europe. Slovenska Komisia pre UNESCO. NK-MOST Bratislava. Slovak.

Gujarati, Damodar. 2004. Basic Econometrics. London: The McGraw-Hill Company. Fourth Edition.

Hashmi, Shabir Mohsin dan Lee,Yap Teck. 2008. Towards East Asian Economic Integration. European Journal of Economics, Finance and Administrative Sciences. Euro Journals Vol. 12. 2008. www. eurojournalsn.com. United Kingdom.

Jhingan, M. L. 1999. Ekonomi Pembangunan dan Perencanaan. Jakarta: PT. Raja Grafindo Persada.

Jitpiromsi, Srisompob dan Kitthaworn, Piya. 2000. The Indonesia-Malaysia-Thailand Growth Triangle (IMT-GT) Project, Implication of Open Regionalism to the Local Economy" Songklanarin Journal of Sciences and Humanities Vol. 6 No. 1. Jan-April 2000. Bangkok.

Kasman. 2009. Pengembangan Perkebunan Karet dalam Usaha Peningkatan Ekonomi Daerah dan Pendapatan Petani di Provinsi Aceh. Jurnal Ekonomi Pembangunan FE UMS. Vol. 10, No.2, Desember. Hlm.114. Surakarta: BPPE Universitas Muhammadiyah Surakarta
Koestoer, Raldi Hendro. 2009. Emerging Issues on Megalopolis Spatial Development in Urban-Fringe Disparities: Perspectives on IMT Cases. Lecture Notes on Megalopolis Spatial Planning-Management. Jakarta.

Krugman, Paul R. dan Obstfeld, Maurice. 2004. Ekonomi Internasional, Teori dan Kebijakan (Terjemahan). Jakarta: PT. Nagarita Dinamika.

Lim, Linda. 1996. ASEAN New Modes of Economic Cooperation, South East Asia in the New World Order: The political Economy of a Dynamic Region. New York: St. Martin Press.

Muhklis, Imam. 2009. Analisis Dampak Integrasi Ekonomi ASEAN terhadap Permintaan Impor Industri Manufaktur Indonesia Tahun 19802005. Paper. Fakultas Ekonomi Universitas Brawijaya. www.fe. ub.ac.id. Malang.

Ooi, Giok-Ling. 1995. The Indonesia-MalaysiaSingapore Growth Triangle: Subregional Economic Cooperation and Integration. Geo-Journal Vol. 12 No. 7. 1995. Singapore.

Republik Indonesia. 2001. Keputusan Presiden Republik Indonesia Nomor 13 Tahun 2001 Tentang Tim Koordinasi Kerjasama Ekonomi Subregional. Jakarta: Kementerian Koordinator Bidang Ekonomi dan Keuangan.

Rodrik, Dani. 2000. How Far Will International Economic Integration Go Journal of Economic Perspective. Volume 14 No. 1. 2000. Harvard University. USA.

Sahman, Andi. 2007. Kerjasama Ekonomi SubRegional. Bulletin Edisi-47/KPI/2007. Direktorat Jendral Kerjasama Perdagangan Internasional. Departemen Perdagangan. Jakarta.

Salvatore. 2004. Ekonomi Internasional (Terjemahan). Jakarta: PT. Gelora Aksara Pratama.

Santoso, Ferry. 1 Juni 2009. Menguji Implementasi Free Trade Zone (FTZ). Kompas.

Sjafrizal. 2008. Ekonomi Regional Teori dan Aplikasi. Padang: Baduose Media. 
Soesastro, Hadi. 2004. Dari Perdagangan Bebas Menjadi Pasar Bebas ASEAN. Jakarta: Penerbit Central Strategic for International Studies.

Soesastro, Hadi. 2004. Daya Saing, Liberalisasi, Globalisasi, Regionalisasi dan Semua Itu. Jakarta: Central Strategic for International Studies.

Supranto, J. 1988. Statistik Deskriptif. Jakarta: Airlangga.

Tambunan, Tulus. 2000. Perdagangan Internasional dan Neraca Pembayaran, Teori dan Temuan Empiris. Jakarta: LP3ES.

Todaro, MP. 2006. Development Economics. England: Longman Inc Ninth Edition.

Utomo, Bambang Budi. 2006. Pembangunan di Sumatera dalam Konteks IMT-GT: Sebuah Masukan dalam Rangka Koordinasi Antara Depbudpar Dengan Pemda Di Kawasan IMTGT Sumatera. Laporan. Jakarta: Puslitbang Arkeologi Nasional. Depbudpar.

www.adb.org (Asian Development Bank). diunduh setiap bulan 2008-09. www.aseansec.org (ASEAN Secretariat). diunduh setiap bulan 2008-09.

www.bi.go.id (Bank Indonesia). diunduh setiap bulan 2008-09.

www.bps.go.id (Badan Pusat Statistik). diunduh setiap bulan 2008-09.

www.ekon.go.id (Kementerian Koordinator Bidang Perekonomian). diunduh setiap bulan 2008-09.

www.imtgt.org (IMT-GT Secretariat). diunduh setiap bulan 2009.

www.kpi.degdag.go.id (Direktorat Jenderal Kerjasama Perdagangan Internasiomal. Departemen Perdagangan). diunduh setiap bulan 2009.

www.pksi.depkeu.go.id (Pusat Kerjasama Internasional. Departemen Keuangan). diunduh setiap bulan 2009.

www.setneg.go.id (Sekretariat Negara). diunduh setiap bulan 2009 . 